\title{
Fetal gene therapy under the microscope...
}

Woshingtok The Heocmbinam-DNA Advsery Ceminitec (KAC) of the US Natioral

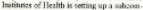
unittee wocesidar the cutit? isues likely 10 be raisot by pane theraps = foten.

Thrs decsiar folbus = earaing inar Philis Nivgathi, bros of the divisien of cellitar and eene thevpyat be US Focd and

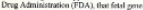
thengy eill sase be a ralistic posoilnility:

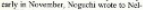
son Wival, chair of lae ILAC. siting some of the ethoul issuss that uill ariec.

One of the nose importare touss mont at last wock's mecting of the cotratitree was

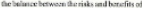

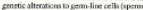
and eges) that would. as z resilt, be passed 6) naberupumt eenernoses

At prosent. yoin Geapy trials me of: boucd anly on sonatie odlis in wals and ithilion sns ary changes ere therefor wos horaditury. Hwetighon scking acprowa? Sor protiools neis show that the vecter carvic2 lew pecetis mefesial will not inferpcesir material ims atrat-line cells.

\section{...as US bans 'embryos for research'}

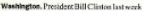
issiractial Hanclat Varnis, the cinectec of

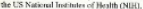
tort bo fand experimenes on hamen rmeryns fertiliond operifivally sor sesarek. The ban cerre aly hiars afler are of the NIH's

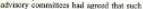
reserne should be allowetd a proscal if cetien cimumadact.

Whathar io formet this cless of expeci ments is part of a lecod ctheal dehate garrounding research vel lnatien emlayos. Clinese', wwif nopsnse apoears on be at

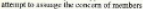
of the aes Repubtican-dariasini Carenes who will sike aes sests in Jasaby:

The rascrimasutation to procecd comes in $\mathrm{z}$ resent frem NTH $x$. Fures Fimbre Aessanes Pased. At last ene mamhar of Cancrexs.

Robers Durmas TRepablikan.Cal furnig) - fied kith pis and the tepre's schar rec. ominendatiens "appalling and of feris of

Dornes pless. tupeper the NH bed in cangressional leatiags and eith itret leg.

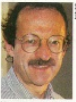

Varmuas ander nes polltiteal pressues. islation if it trins to proceted with revarch usiag laman Gabrych. If he does be will hwe at hast one pows fid ally. In Septem. bor, Nowt Oagnch. the nes Repahtinie spesios of the liause of Repervereagives.

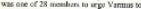
njact ibe findings of the NTH pand

The criges of the furoos lie in a daciskan

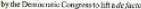

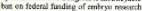
whes Clince fook othes two ytari apo. In theory, the NHH sirlet nt thit pont have heded enteryo sescaech propesals lestead. Vammenpourfed a patel to alviseon prideliates for entryo pexach. This conelaled that, if certaia chastraints are met, reseorch in mntrove is acraptihle is the the forr 1senth day, wher ite somallind rrimitive rrack appean.

Before the abpearance of the gramisue stroke. the enoryo is $x$ collection of aedifresatiused scllx it an divide into

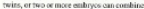
so form one embro. Ronald Cisen, a merb ber of the youl ual prodeser ef religgion and

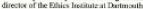
Colbepe, New Heanphire, sass if was the lack of Eitaxisation that convenced the

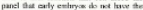
same moeal status as an adde ar ctrild

The pertel decided ear any allevatioes of neffering that mixht resalt from research of

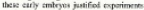

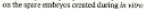
forilimaion inestrmes

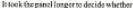
cyos analil be fontilsacd upvifianlly for

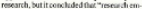

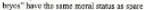

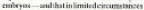
rescurch was acocitabie

Yarmus's atvisery periel alss found this

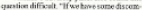

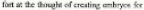

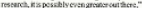
soid Pranely Drvis, professor of sediatros and medicite at Case Westem Reverve Uaiversiry Schoul of Modicine in Cascelind. Otio

Derity lart wrek's prenentation, Sirven

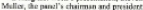

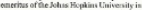
Delimore. peinied sut al a pencal wanemae that a hage mainity of the pohls has no idse what a wor haman ealarya ne-

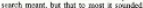
"lerible?"

Catameneing en the White Houre 's ril. inf. $\mathrm{a}$ gocicespersoe for ife NIH wid on Meniry that conesderiscon was arm beifo firct so the pooible esmperitica and no.

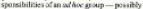
sinilar wo the Rocombisali DNA havesery Comminas - bo noirw all proposals foe restas: h iavolvie laman amicrus it 6

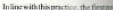

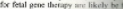
maic stils. But Rosertione Pahina:

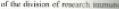

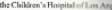

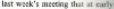

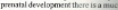
fisk that a vecker will rater all indatirg gorn collia. Inlecd a pupar

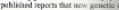
imrodued to the cells of a limb in.

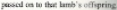

Few atios ba the youl uf purnt cblnentinzadiseare But Alecander

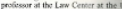

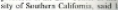
thete ary be ischeical limifatione it proceceires, such as the nosd to ensar tlae pores is inomerveatod in ereactly thr place ard that it seisches an eved aff noth teme.

Asy misule myde lead to a work Iam, vigs Capeen. Bue he dles rays 1

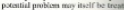
i few years and thet ine sisk may dhet not be asceptable.

Fifal yne therroy would be uf 50 value fie domses ihit to meversihle ise befoes bith or lave a kifh mate of matrality. Bue Nogushr is bitar mane questice af $w$ brstreald be incluiled in

Shculd tatst be women morally of to abotion sor utas setal cene fr. might he an acceotable risk 90 or womam heve eicady socotrod the movit fies a peutic aborties? And love ean woment my well disegest their own healith fiv uake of fie fous, be predicind from enthasestie imedigan?

"Weare tryied i thiak alket these. now. we tur we are resty wben we n. Ilas froi feaneale; " ays Wivel

Helen Oarrach

- As adrisocy gaoup to hacques Detar. providere of the Eircopen Cerrenasios

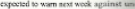
estimatitg that tids of siectarlic venie the - partaodarly gwet ifse publicity sart ite nower discremion of its afety - ant

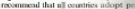

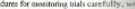
Doviae Buter fhor Ravi

Ansiher filaly moimmondation fraser advisory grame, ofich is chaired by $\mathrm{N}$. Lencir. a trimber of the French conint

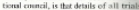
unde puble, und tias the public he be intonened of the sooential risks associ wits the technigise

The grasp is nor expected fo recomumet.

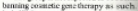

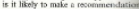
germaline pre theray, on the proumbs ithe elliks of thice ore comples, and thr would be premanae 10 ake a powition at juswnt time. 